\title{
Cnidosac-Related Structures in Embletonia (Mollusca, Nudibranchia) Compared with Dendronotacean and Aeolidacean Species
}

\author{
Rainer Martin ${ }^{*}, 1$, Karl-Heinz Tomaschko ${ }^{2}$, Martin $H e \beta^{3}$ and Michael Schrödl ${ }^{4}$ \\ ${ }^{I}$ Central Electron Microscopy Facility, Universität Ulm, Albert-Einstein-Allee 11, D 89069 Ulm, Germany \\ ${ }^{2}$ Akademie für Gesundheitsberufe, Universitätsklinikum, Schlossstr. 38, D 89079 Ulm, Germany \\ ${ }^{3}$ Biozentrum, Universität München, Großhadernerstr. 2, D 82152 München, Germany \\ ${ }^{4}$ Zoologische Staatssammlung München, Münchhausenstr. 21, D 81247 München, Germany
}

\begin{abstract}
In defense against attack by predators, cnidosacs in the tips of cerata (dorsal appendages) of aeolidacean nudibranchs discharge masses of mature nematocysts that are derived from cnidarian food. Cnidosac-related structures in various nudibranchs may provide a reconstruction of potential steps in the evolution of cnidosacs. Such structures in the cerata of the two valid species of Embletoniidae, an enigmatic nudibranch family, are described in this report, and compared to cnidosacs in dendronotaceans and aeolidaceans. The Embletonia spp. ceratal tips are characterized by cnidophages, which are largely undifferentiated cells that take up the nematocysts from the digestive tract lumen and transport them to different surface locations of the cerata, where they are released. Organized muscular bags that force out the nematocysts, as those found in cnidosacs, are absent. These cnidosac-related structures and other characteristics weaken the case of including Embletoniidae incertae sedis within Aeolidacea.
\end{abstract}

Keywords: Nematocysts, release, defense, cnidosac evolution, nudibranch mollusks.

\section{INTRODUCTION}

Cnidosacs, which are muscular bags in the tips of the dorsal appendages (cerata) of eolid nudibranch mollusks (Aeolidacea) filled with mature nematocysts ( $\mathrm{NCs}$ ) from the cnidarian food, the kleptocnidae, are well known structures $[1,2]$. In eolids they are thought to be defense organs, directed for example against predatory fish [2-4]. Recently, we examined cnidosac-like organs of dendronotacean nudibranchs, which feed on hydroids [5]. Collection of specimens of both valid species of the genus Embletonia Alder and Hancock, 1851 enabled us now to examine cnidosac-like structures in Embletoniidae. This family was considered to belong to eolids, related to the Tergipedidae [6,7], but there were also considerations that argued in favor of a position among dendronotacean nudibranchs [8]. In this respect, presence or absence of cnidosacs is an unaddressed key question. Marcus and Marcus [9] found 'Nesselplatten', terminal pads of nematocysts in the European E. pulchra (Alder and Hancock, 1844), but no real cnidosacs as such, while Baba and Hamatani [10] have observed, "a simplified cnidosac filled with nematocysts" at the ceratal tips of the Indo-Pacific E. gracile Risbec, 1928 (as Embletonia gracilis paucipapillata Baba and Hamatani, 1963). In the latter species, Rudman [7] also has observed "sacs containing nematocysts at the ceratal tips".

In this report, we describe the cnidosac-like tissue in the cerata tips of E. pulchra and E. gracile and compare these

*Address correspondence to this author at the Central Electron Microscopy Facility, Universität Ulm, Albert-Einstein-Allee 11, D 89069 Ulm, Germany; Tel: 0049731 5023441; Fax: 0049731 5023383; E-mail: rainer.martin@uni-ulm.de structures to those found in the dendronotaceans Doto acuta and Hancockia spp., as well as to eolid cnidosacs. Embletonia spp. structures may represent an early stage in the evolution of cnidosacs.

\section{MATERIALS AND METHODOLOGY}

Eleven small specimens of E. pulchra were extracted from coarse sand collected at $9 \mathrm{~m}$ depth off Cape Savudrjia, Istria (Croatia, Adriatic Sea). They were immersed in fixative consisting of $2 \%$ paraformaldehyde and $2 \%$ glutaraldehyde in artificial seawater buffered with $0.1 \mathrm{~mol}^{-1} \mathrm{Na}-$ cacodylate, $\mathrm{pH}$ 7.6. Specimens of E. gracile were collected from coarse subtidal sand at Lembeh Strait, northern Sulawesi, and conserved in $70 \%$ ethanol. In the lab, the specimens were osmicated, dehydrated in graded propanol series and embedded in Epon (Fluka/Sigma, Steinheim, Germany). They were contrasted with $0.2 \mathrm{~g} / 1$ uranyl acetate dissolved in $95 \%$ ethanol, between propanol $90 \%$ and propanol $100 \%$. Specimens of E. pulchra were processed for light and transmission electron microscopy, and E. gracile for light microscopy only.

Tomographic reconstructions of the distal cerata were based on serial, cross or longitudinal, $500 \mathrm{~nm}$ thick sections, cut with a diamond knife. The sections were mounted on glass slides and stained with toluidine blue solution, diluted 1:15 with water. Digital images of the sections were recorded with a CCD-camera on a light microscope with $\times 40$ or $\mathrm{x} 100$ phase contrast objectives. In order to determine the correct pixel scale, a calibrated object micrometer scale was photographed. The primary images were contrast enhanced in Adobe Photoshop and imported into the AMIRA 3Drendering software (TGS graphics). After stack alignment 
and manual segmentation of the structures of interest in every single section, colors were assigned to the contours obtained, which were then subjected to surface rendering and smoothing procedures. After free rotation, selected AMIRA projections were stored as tif-formatted images.

\section{RESULTS}

A characteristic adaptation in E. pulchra is the uptake of NCs from the digestive gland lumen by a specific cell type, the cnidophages, which then transport the NCs to the apical surface of the ceras (Figs. 1 and 2). Cnidophages are otherwise undifferentiated cells with very little cytoplasm, $i$. e., a type of stem cells. Intact cells with their NCs migrate to the apical surface of the ceras, where they are incorporated into the epidermis, undergo disintegration and release the NCs. Thus, the vectors of NC-transport and expulsion are the cnidophage cells. There are no organized muscular sacs. The longitudinal muscles beneath the cerata epidermis divide on top of the digestive gland and form a septum, which separates the digestive compartment from the $\mathrm{NC}$ expulsion compartment (Fig. 1b). As compared to eolid cnidosacs the orientation of the muscle cells appears unordered, and a central opening forming a sphincter is absent. The muscular septum leaves multiple passages through which the cnidophages can migrate from the digestive part. The multiple release sites of the NCs from the cnidophages were at the round distal ends of the cerata. While our specimens of $E$.
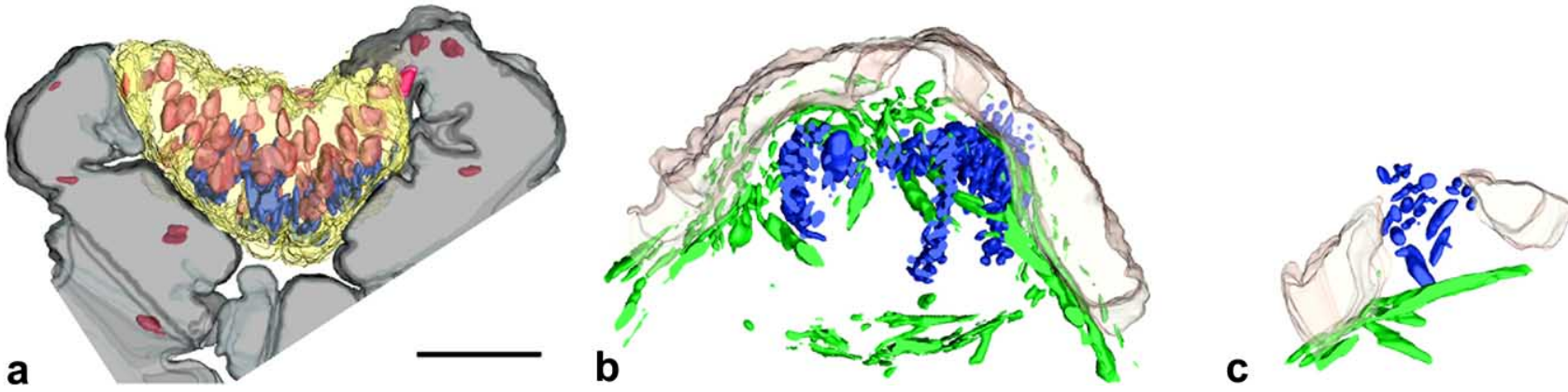

Fig. (1). Tomographic reconstructions of different areas of three different cerata of Embletonia pulchra, from proximal (a) to distal (b, c). NCs (nematocysts): blue; cnidophages: yellow; muscles: green; nuclei: red; digestive cells (a): dark grey; epidermis (b, c): light grey. The cnidophages take up NCs from the digestive tract lumen (a) and migrate to the cerata tips, where they form clusters within a bed of irregularly oriented muscles (b). In (c) one of these clusters has penetrated the epidermis during release of NCs. Bar: $25 \mu \mathrm{m}$.
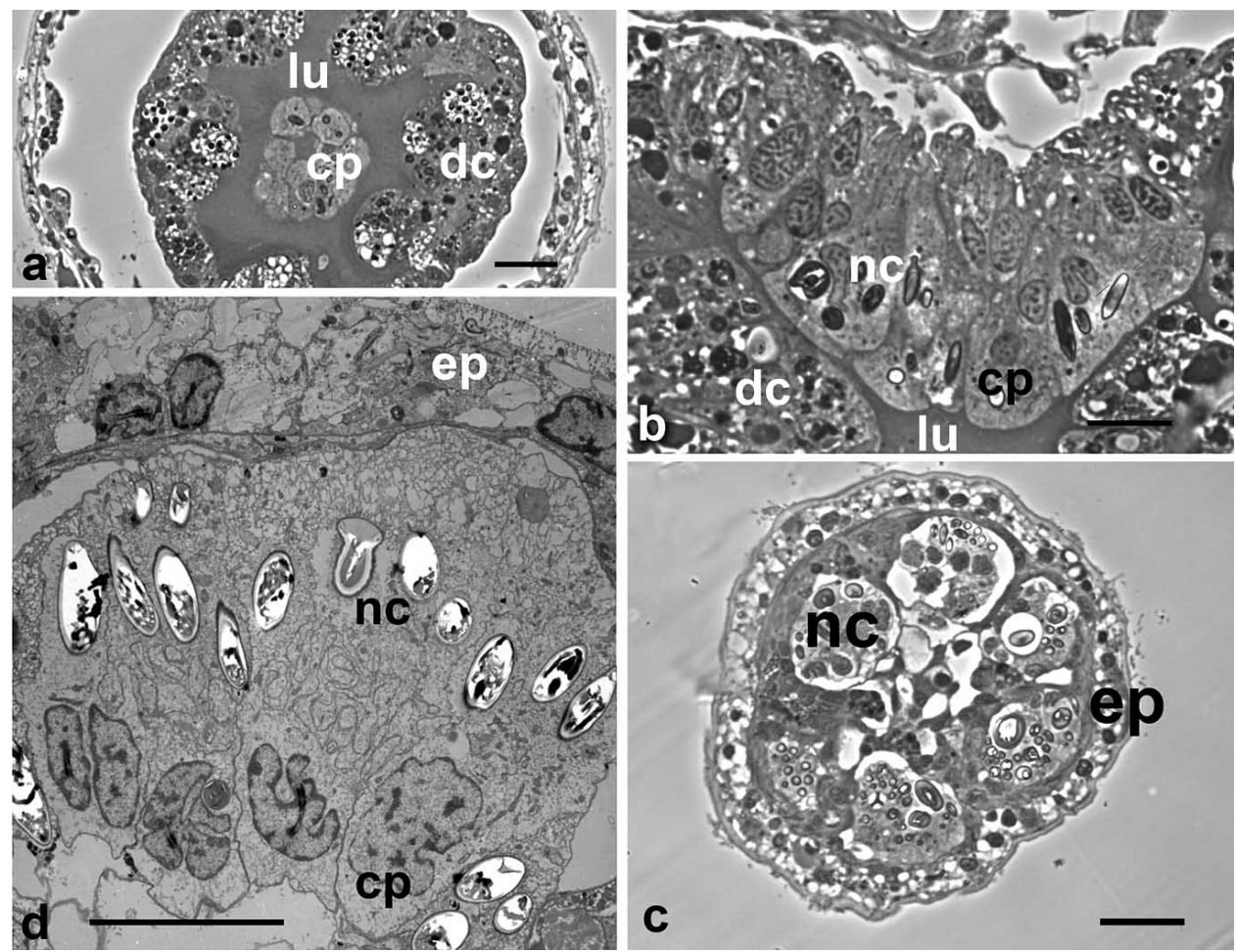

Fig. (2). Light (a, b, c) and an electron micrograph (d) of different cerata of Embletonia pulchra, in different areas from proximal (a, b) to distal (c, d). In (a) (cross section) and (b) (longitudinal section) the group of cnidophages (cp) in the center take up NCs (nc) from the cerata lumen (lu), surrounded by digestive cells (dc). In (c) (cross section) and (d) (longitudinal section) the cnidophages form cell clusters with NCs underneath the epidermis (ep). Bars: (a) and (c) $20 \mu \mathrm{m}$; (b) and (d) $10 \mu \mathrm{m}$. 
pulchra had rounded cerata ends, other specimens were shown to form short apical ceratal projections [11], which contained groups of cnidophages [9]. Cerata of E. gracile were apically divided [see also refs. 10,8,7], with NCreleasing cnidophage groups ("pads") located on pedestallike structures. Discharging NCs with extruded NC-threads were not seen in our specimens, but in the study of Marcus and Marcus [9] many NCs had discharged, presumably an effect of the fixative applied.

\section{DISCUSSION}

A sequence with increasing accumulation of NCs, improvement of the expulsion mechanisms and concentration in a single release site may be seen when cerata tips of four different species in different families are compared (Fig. 3). In Doto acuta, which does not have cnidosacs, about $90 \%$ of the NCs were found in heterolysosomes of digestive cells in varying state of digestion [5]. The small Doto acuta feeds by sucking at hydroid stolons, presumably devouring fewer NCs than animals feeding on hydroid tentacles. In addition, these $\mathrm{NCs}$ are inferred to be premature and, therefore, more easily digested. This likely means that NCs are handled like other food components in this cryptic, bottom-living species (Fig. 3a).

In the two Embletonia species, which live hidden in coarse sand, NCs of unknown origin are exclusively taken up by a special, non-digestive cell type, the cnidophages and released via cell lysis at varying sites of the cerata tips (Fig. 3b). It is a process of expulsion and elimination of a food component, which presumably is hard to digest. The costly process of $\mathrm{NC}$ digestion in lysosomes with their pool of enzymes has disappeared. The cerata tips serve as an excretory organ. Apparently all NCs were taken up by cnidophages and released at the cerata tips. However, Marcus and Marcus [9] found spirocysts of sea anemones in the distal digestive cells, but not in the cnidophages. This would suggest a selection process, in which NCs are directed into the cnidophages, and spirocysts into the digestive cells.

Moreover, NCs are taken up from the digestive canal lumen by cnidophages in dendronotacean Hancockia spp. (Fig. 3c). Accumulations of NC-laden cnidophages are then found in muscular bags with a sphincter and an opening for release, i.e. authentic cnidosacs [5]. The number of NCs per cnidosac is limited, as compared to the eolid cnidosacs, due to the cellular transport through a narrow sphincter. There are numerous small cnidosacs per ceras. Thus, in these dendronotaceans the NC-expulsion process is enhanced, but the release sites are distributed over the cerata.

In eolid cnidosacs, which are much larger than the Hancockia spp. cnidosacs, a single, unique innovation has led to the accumulation of masses of NCs in the cnidosacs; namely, exposed, naked NCs are transported directly through the sphincter opening from the digestive gland lumen by ciliary propulsion (Fig. 3d) [5,12]. Cnidophages devoid of $\mathrm{NCs}$ enter the cnidosacs, where they then accumulate very large numbers of NCs and disintegrate. The incorporation of NCs into cnidophages not before but after passage through

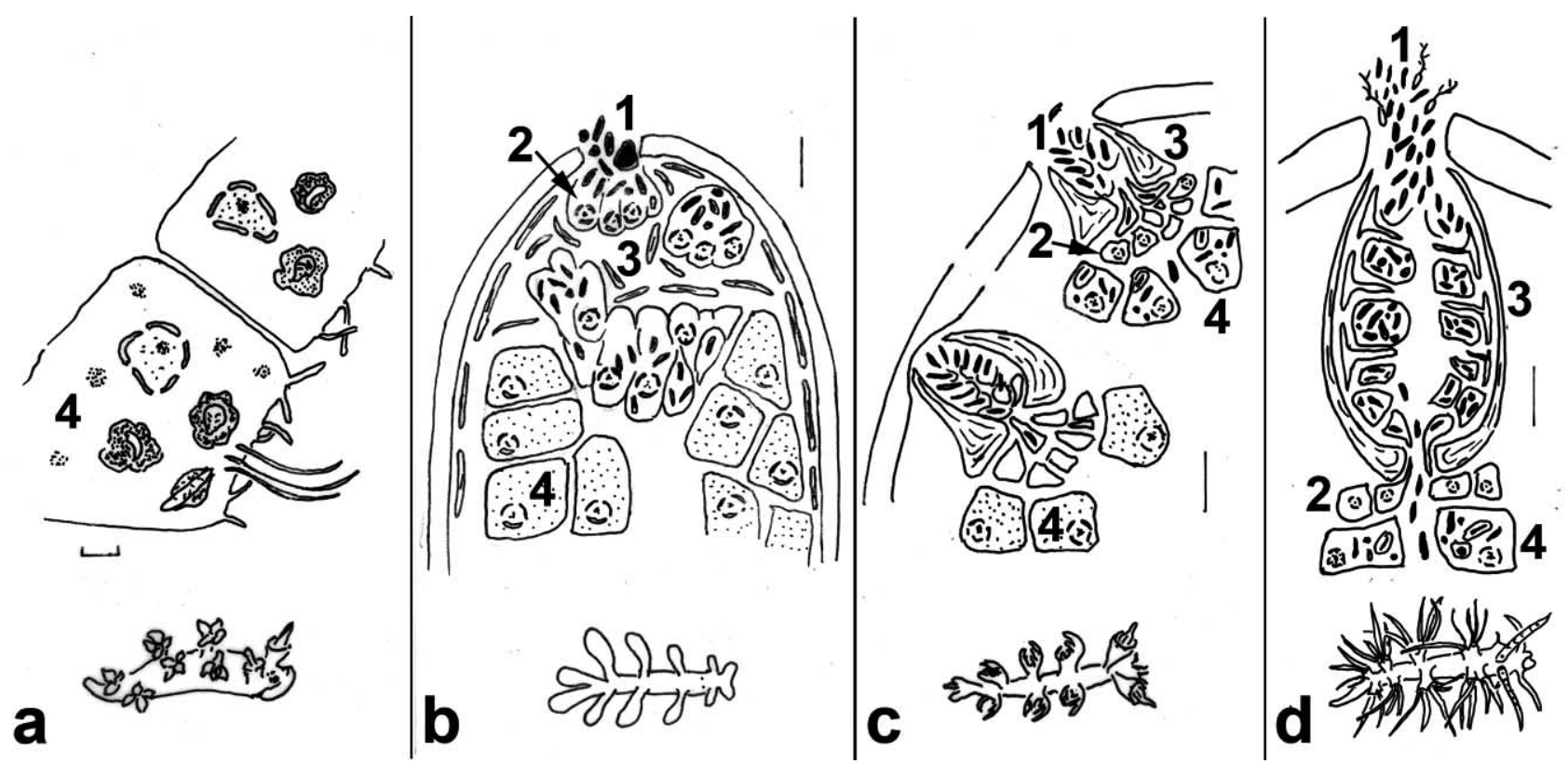

Fig. (3). Schematic drawings of distal cerata areas of Doto acuta (a), Embletonia spp. (b), Hancockia spp. (c), and Flabellina affinis (d). In Doto sp. (a) NCs are phagocytosed by digestive cells (4) and digested in lysosomes; there are no cnidosac-like structures. Muscular cnidosacs (3) are found in Hancockia spp. (c) and in Flabellina affinis (d). The cnidosac of the latter (d) is much larger and stores many more NCs (1), which are transported by cilia into the cnidosac. In Hancockia spp. cnidophages (2) with few NCs squeeze through the muscular sphincter. In Embletonia spp. (b) cnidophages with NCs migrate to the ceras tip, where they penetrate the epidermis and release the NCs; a muscular cnidosac does not exist. 
the sphincter opening has allowed the storage of many more NCs. A single release site of these NC-laden cnidosacs is located in the tip of each of the usually unbranched cerata of eolids.

Due to the concentration of masses of mature NCs in muscular bags, which form the tips of the cerata, a most strategically exposed location with respect to the whole animal, eolid cnidosacs provide a NC-release function, and serve as efficient defense organs.

While the homologous versus convergent origin(s) of cnidosacs in the dendronotaceans Hancockia spp. and eolids is still unclear, the special cnidosacs with sphincter and cnidophages storing multiple NCs can be considered as unambiguous synapomorphies of eolids. In contrast to earlier observations [7], Embletoniidae do not possess cnidosacs at all and, thus, lack the important apomorphic character complex attributed to eolids [13,14]. Oral veil-like lobes [8], but not characteristic and apomorphic eolid oral tentacles [13], are developed in Embletonia spp. Apart from having an eolid-like elongate body shape and an uniseriate radula, there is little reason left for a taxonomic placement within the Aeolidacea.

In revising the internal taxonomy of Embletoniidae considerable attention has been paid to the shape of cerata. Subapical ramifications, often with apical subdivisions [7] are more or less clearly developed in all growth stages of $E$. gracile [8]. While often described as having round, smooth apices, apical bifid outgrowths are also detectable in larger animals of E. pulchra [11]. Thus, embletoniid cerata can be regarded as at least slightly ramified, notal outgrowths; Embletonia spp. cerata reflect the name-bearing character of Dendronotacea. The particular pairwise arrangement of cerata also resembles dendronotacean rather than eolid taxa, which usually show smooth cerata arranged in patches or rows.

On the other hand, rhinophoral sheaths as present in dendronotaceans, are absent in Embletoniidae [7]. From a morphological point of view, Embletoniidae may well be a basal dendronotacean offshoot; yet alternative placements, such as at the base of eolids cannot be excluded. Integrating data of Embletonia spp. into the cladistic analysis of Wägele and Willan [13], the strict consensus tree recovers these species within paraphyletic Aeolidacea (tree not shown). Embletoniidae result as part of a non-supported, polytomic clade of eolid genera such as Tergipes spp., Cuthona spp., Eubranchus spp., Phyllodesmium spp. and Protaeolidia spp., as sister group to Hancockia spp. and Doto spp. Including Embletoniidae into comprehensive morphology-based and molecular systematics is overdue to resolve its relationships, and, hence, the homology and direction in the evolution of NC-storing organs and functions.

\section{CONCLUSIONS}

A specialized protective skin and stomach epithelium $[15,16]$ enables nudibranchs to invade an aversive and highly hostile biotic niche with abundant food, cnidaria polyps and sea anemones. This food includes masses of NCs with thick capsules that apparently resist digestion. Different methods have evolved in nudibranchs for the release of intact, mature
NCs. They include uptake from the intestinal tract by a specialized cell type, the cnidophages, and transport to the exterior, as exemplified by Embletonia species. In the dendronotacean Hancockia spp., cnidophages are wrapped in muscular bags that force out the NC payload. In the tips of the usually long, unbranched cerata of aeolidacean species, structures with organ character have evolved, the cnidosacs, which accumulate masses of NCs in a muscular bag, store them for many days and discharge NCs when attacked. We conclude that a second function, namely, the use of NCs in defense, is superimposed on a basic function, which is the elimination of an excess of undigestible food particles. The absence of cnidosacs in Embletoniidae and the ramified nature of their cerata weakens the case for including this enigmatic family within Aeolidacea.

\section{ACKNOWLEDGEMENTS}

We thank the University of Manado for support of our field activities in Sulawesi. Dirk Eheberg and Rosana Carvalho-Schrödl (ZSM) helped sorting sand samples. Field work was supported by the GeoBioCenter of the LMU and the German Research Foundation (DFG SCHR667/3 and $667 / 4$ to MS). We thank Prof. Paul Walther, for hospitality and use of the facilities of the Central Electron Microscopy Unit, University of Ulm, and Prof. E. Koenig (Buffalo, U.S.A.) for criticism and linguistic corrections.

\section{REFERENCES}

[1] Wright TS. On the cnidae or thread-cells of the Eolidae. Proc Roy Phys Soc Edinburgh 1859(for 1858); 2: 38-40.

[2] Grosvenor GH. On the nematocysts of aeolids. Proc Roy Soc London 1903; 72: 462-86.

[3] Herdman WA. Some experiments on feeding fishes with nudibranchs. Nature 1890; 42: 201-3.

[4] Edmunds M. Protective mechanisms in the Eolidacea (Mollusca: Nudibranchia). J Linn Soc Zool 1966; 47: 27-71.

[5] Martin R, Heß M, Schrödl M, Tomaschko KH. Cnidosac morphology in dendronotacean and aeolidacean nudibranch mollusks: from expulsion of nematocysts to use in defense? Mar Biol 2009; 156: 261-8.

[6] Schmekel L, Portmann A. Opisthobranchia des Mittelmeeres. Nudibranchia und Saccoglossa. Berlin Heidelberg New York: Springer 1982.

[7] Rudman WB. Embletonia gracilis Risbec, 1928. Sea Slug Forum 2002; Australian Museum, Sydney. Available from: http://www. seaslugforum.net/factsheet/emblgrac

[8] Miller MC, Willan RC. Redescription of Embletonia gracile Risbec, 1928 (Nudibranchia: Embletoniidae): relocation to suborder Dendronotacea with taxonomic and phylogenetic implications. J Moll Stud 1991; 58: 1-12.

[9] Marcus E, Marcus E. Opisthobranchia aus dem Schill von Helgoland. Kieler Meeresforsch 1958; 14: 91-6.

[10] Baba K, Hamatani I. Anatomy of Embletonia gracilis paucipapillata n. ssp. from Osaka Bay, Japan (NudibranchiaEolidoidea). Publ Seto Mar Biol Lab 1963; 11: 399-403.

[11] Martynov A. Embletonia pulchra - first record from subarctic. Sea Slug Forum 2007; Australian Museum, Sydney. Available from: http://www.seaslugforum.net/find/19935.

[12] Martin R. Management of nematocysts in the alimentary tract and in cnidosacs of the aeolid nudibranch gastropod Cratena peregrina. Mar Biol 2003; 104: 533-41

[13] Wägele H, Willan RC. Phylogeny of the Nudibranchia. Zool J Linn Soc 2000; 113: 83-181.

[14] Wägele H, Klussmann-Kolb A. Opisthobranchia (Mollusca, Gastropoda) - more than just slimy slugs. Shell reduction and its implications on defence and foraging. Front Zool 2005; 2: 1-18. 
[15] Martin R, Tomaschko KH, Walther P. Protective skin structures in shell-less marine gastropods. Mar Biol 2007; 150: 807-17.
[16] Martin R, Hild S, Walther P, Ploss K, Boland W, Tomaschko KH. Granular chitin in the epidermis of nudibranch mollusks. Biol Bull 2007; 213: 307-15.

Received: May 20, 2010

(C) Martin et al.; Licensee Bentham Open.

This is an open access article licensed under the terms of the Creative Commons Attribution Non-Commercial License (http://creativecommons.org/licenses/bync/3.0/), which permits unrestricted, non-commercial use, distribution and reproduction in any medium, provided the work is properly cited. 